\title{
Short wave-automated perimetry (SWAP) versus optical coherence tomography in early detection of glaucoma [Corrigendum]
}

\author{
Zaky AG, Yassin AT, El Sayid SH. Clin Ophthalmol. 2016;10: \\ 1819-1824.
}

Page 1819, Abstract, Patients and methods, line 1, "In this randomized controlled, consecutive, prospective study" should read "In this non-randomized, controlled crosssectional study".

Page 1820, left column, Patients and methods, line 1, "This consecutive prospective study" should read "This nonrandomized, cross-sectional study".

Page 1820, left column, Patients and Methods, Exclusion criteria section, line 5 , "pachymetry $>480 \mu \mathrm{m}$ or $<540 \mu \mathrm{m}$ " should read "pachymetry $<480 \mu \mathrm{m}$ or $>540 \mu \mathrm{m}$ ".
Page 1821, left column, Results section, line 13, "RNFL thickness measured by OCT was outside normal limits in at least 1 hour in 7 eyes" should read "RNFL thickness measured by OCT was outside normal limits in 1 hour in 7 eyes".

Page 1821, right column, Results section, line 12, "RNFL thickness measured by OCT was outside normal limits in at least 1 hour in 9 eyes" should read "RNFL thickness measured by OCT was outside normal limits in 1 hour in 9 eyes".

Page 1821, Table 1 is incorrect, the correct Table is shown below:

Table I Demographic features among three groups

\begin{tabular}{|c|c|c|c|c|c|}
\hline Variable & Case group & Suspect group & Control group & $F$ test & $P$-value \\
\hline \multicolumn{6}{|l|}{ Age } \\
\hline Mean \pm SD & $55.32 \pm 9.22$ & $43.7 \pm 12.92$ & $44.95 \pm 9.76$ & 18.09 & 0.001 \\
\hline \multicolumn{6}{|l|}{ Sex, n (\%) } \\
\hline Male & $10(33.3)$ & $10(33.3)$ & $5(50.0)$ & $\mathrm{FET}=37.93$ & 0.001 \\
\hline Female & $20(66.7)$ & $20(66.7)$ & $5(50.0)$ & $\mathrm{FET}=37.93$ & 0.001 \\
\hline
\end{tabular}

Abbreviation: FET, Fisher's exact test.

Clinical Ophthalmology

\section{Publish your work in this journal}

Clinical Ophthalmology is an international, peer-reviewed journal covering all subspecialties within ophthalmology. Key topics include: Optometry; Visual science; Pharmacology and drug therapy in eye diseases; Basic Sciences; Primary and Secondary eye care; Patient Safety and Quality of Care Improvements. This journal is indexed on
PubMed Central and CAS, and is the official journal of The Society of Clinical Ophthalmology (SCO). The manuscript management system is completely online and includes a very quick and fair peer-review system, which is all easy to use. Visit http://www.dovepress.com/ testimonials.php to read real quotes from published authors. 